\title{
ANALISIS PASOKAN PANAS PADA PRODUKSI HIDROGEN PROSES STEAM REFORMING KONVENSIONAL DAN NUKLIR
}

\author{
Siti Alimah, Djati Hoesen Salimy \\ Pusat Kajian Sistem Energi Nuklir (PKSEN)-BATAN \\ Jl. Kuningan Barat, Mampang Prapatan, Jakarta Selatan, 12710 \\ Phone/Fax : (021) 5204243, E-mail : alimahs@batan.go.id
}

\begin{tabular}{|c|c|c|}
\hline Diterima & Diterima dalam bentuk revisi & Disetujui \\
\hline 03 Februari 2015 & 27 April 2015 & 12 Mei 2015 \\
\hline
\end{tabular}

\begin{abstract}
ABSTRAK
ANALISIS PASOKAN PANAS PADA PRODUKSI HIDROGEN PROSES STEAM REFORMING KONVENSIONAL DAN NUKLIR. Telah dilakukan analisis pasokan energi panas pada produksi hidrogen dengan proses steam reforming gas alam. Tujuan studi adalah untuk memahami sistem pasokan energi panas konvensional dan dengan nuklir. Metodologi yang digunakan adalah kajian literatur dan analisis berdasar perbandingan. Hasil studi menunjukkan bahwa proses dengan sumber panas bahan bakar fosil (gas alam) mampu memberikan kondisi operasi optimum temperatur 850-900 $\mathrm{C}$ dan tekanan 2-3 MPa, serta dengan perpindahan panas didominasi oleh perpindahan panas radiasi, sehingga fluks panas yang dapat dicapai pada tabung katalisator relatif tinggi $\left(50-80 \mathrm{~kW} / \mathrm{m}^{2}\right)$ dan menghasilkan efisiensi thermal yang tinggi yaitu sekitar $85 \%$. Sedang pada sistem dengan energi nuklir, karena tuntutan keselamatan, proses beroperasi pada kondisi yang kurang optimum temperatur 800-850 $\mathrm{C}$ dan tekanan 4,5 MPa, serta dengan perpindahan panas didominasi oleh perpindahan panas konveksi, sehingga fluks panas yang dapat dicapai pada tabung katalisator jauh lebih rendah (10-20 $\mathrm{kW} / \mathrm{m}^{2}$ ) dan menghasilkan efisiensi thermal yang rendah sekitar 50\%. Modifikasi reformer dan utilisasi panas mampu meningkatkan fluks panas sampai $40 \mathrm{~kW} / \mathrm{m}^{2}$ sehingga efisiensi thermal dapat mencapai 78\%. Meskipun demikian, aplikasi energi nuklir untuk produksi hidrogen dengan proses steam reforming mampu menghemat pembakaran bahan bakar fosil yang berimplikasi pada potensi penurunan laju emisi $\mathrm{CO}_{2}$ ke lingkungan.
\end{abstract}

Kata kunci: produksi hidrogen, steam reforming, reformer, HTGR

\begin{abstract}
HEAT SUPPLY ANALYSIS OF STEAM REFORMING HYDROGEN PRODUCTION PROCESS IN CONVENTIONAL AND NUCLEAR. The analysis of heat energy supply in the production of hydrogen by natural gas steam reforming process has been done. The aim of the study is to compare the energy supply system of conventional and nuclear heat. Methodology used in this study is an assessment of literature and analysis based on the comparisons. The study shows that the heat sources of fossil fuels (natural gas) is able to provide optimum operating conditions of temperature and pressure of $850-900^{\circ} \mathrm{C}$ and 2-3 $\mathrm{MPa}$, as well as the heat transfer is dominated by radiation heat transfer, so that the heat flux that can be achieved on the catalyst tube relatively high $\left(50-80 \mathrm{~kW} / \mathrm{m}^{2}\right)$ and provide high thermal efficiency of about $85 \%$. While in the system with nuclear energy, due to the demands of safety, process operating at less than optimum conditions of temperature and pressure of $800-850^{\circ} \mathrm{C}$ and 4.5 MPa, as well as the heat transfer is dominated by convection heat transfer, so that the heat flux that can be achieved catalyst tube is relatively low $\left(10-20 \mathrm{~kW} / \mathrm{m}^{2}\right)$ and it provides a low thermal efficiency of about $50 \%$. Modifications of reformer and heat utilization can increase the heat flux up to $40 \mathrm{~kW} / \mathrm{m}^{2}$ so that the thermal efficiency can reach $78 \%$. Nevertheless, the application of nuclear energy to hydrogen production with steam reforming process is able to reduce the burning of fossil fuels which has implications for the potential decrease in the rate of $\mathrm{CO}_{2}$ emissions into the environment.
\end{abstract}

Keywords: hydrogen production, steam reforming, reformer, HTGR 


\section{PENDAHULUAN}

Para pakar energi di negara maju seperti Amerika, Jepang dan Eropa sepakat bahwa hidrogen sangat dimungkinkan menjadi alternatif bahan bakar masa depan ${ }^{[1]}$. Di samping sebagai bahan baku industri petrokimia, hidrogen juga merupakan energi carrier masa depan. Sebagai salah satu bahan bakar, hidrogen mempunyai heating value yang tinggi dan ramah lingkungan. Pembakaran hidrogen hanya menghasilkan uap air, sehingga memberikan nilai Global Warming Potential $(\mathrm{GWP})=0$ dan Ozone Depletion Potential $(\mathrm{ODP})=$ 0 . Satu kg hidrogen mempunyai kandungan energi $143 \mathrm{MJ}$ atau setara dengan 5 liter gasoline $^{[2]}$.

Sebagai energi masa depan, hidrogen berperan sebagai medium pembawa energi (energy carrier) dan bukan sumber energi primer, karena hidrogen bukanlah senyawa yang terdapat bebas di alam ${ }^{[3]}$. Proses komersial yang mendominasi produksi hidrogen saat ini adalah proses steam reforming gas alam. Diperkirakan lebih dari $85 \%$ produksi hidrogen dilakukan dengan proses ini. Untuk memproduksi hidrogen dibutuhkan energi guna melepaskan ikatan antara atom hidrogen dengan unsur lain. Energi tersebut dapat diperoleh dari sumber energi primer antara lain bahan bakar fosil dan energi panas nuklir. Saat ini energi primer untuk produksi hidrogen yang berasal dari bahan bakar fosil mencapai $96 \%$, dengan komposisi $48 \%$ dari gas alam (metana), 30\% dari minyak dan $18 \%$ dari batubara ${ }^{[4]}$. Sisanya sekitar 2\% dari sumber elektrolisis klor alkalin dan 2\% dari gasifikasi biomassa.

Steam reforming dengan bahan baku gas alam adalah teknologi yang telah terbukti pada skala industri, yang beroperasi dengan kondisi operasi temperatur tinggi yaitu dalam kisaran $750-900^{\circ} \mathrm{C}$, tekanan 2-3 MPa dengan bantuan katalisator berbasis nikel dan prosesnya sangat endotermis. Panas temperatur tinggi tersebut dipasok dari tungku dengan bahan bakar fosil (gas alam). Jadi gas alam selain sebagai bahan baku, juga dibakar untuk memproduksi panas temperatur tinggi untuk proses. Operasi proses kimia endotermis pada temperatur tinggi berimplikasi pada diperlukannya energi thermal dalam jumlah besar. Secara konvensional, kebutuhan energi panas dipasok dari bahan bakar fosil gas alam. Sejumlah studi dan pengalaman empiris menunjukkan bahwa sekitar $40 \%$ kebutuhan gas alam pada produksi hidrogen dibakar sebagai sumber energi[5,6]. Jika energi panas dapat digantikan dengan energi nuklir, diharapkan dapat diperoleh keuntungan dari sisi penghematan bahan bakar fosil yang berimplikasi pada pengurangan laju emisi $\mathrm{CO}_{2}$ dan diversifikasi reaktor nukliris].

Konsep aplikasi energi nuklir sebagai sumber energi (panas dan listrik) bagi industri telah dikaji lebih dari 50 tahun. Reaktor temperatur tinggi berpendingin gas (HTGR/High Temperature gas-Cooled Reactor) yang beroperasi pada temperatur tinggi $\left(\sim 950^{\circ} \mathrm{C}\right)$ diperkirakan merupakan jenis reaktor yang sangat potensial menyumbangkan produksi energinya untuk kebutuhan industri. Jika sampai saat ini dari reaktor nuklir komersial hanya menghasilkan listrik, ada suatu prediksi bahwa nantinya reaktor nuklir juga bisa menghasilkan hidrogen sebagai energi alternatif[1,7]. Luaran panas yang dibawa gas helium sebagai pendingin HTGR, dapat dimanfaatkan untuk kebutuhan proses steam reforming gas alam. HTGR adalah salah satu jenis pembangkit listrik tenaga nuklir yang berpotensi memproduksi panas untuk diaplikasikan dalam proses industri seperti proses steam reforming gas alam, dengan temperatur keluaran pendingin dapat mencapai sekitar 750$950^{\circ} \mathrm{C}$. Di dalam proses industri, keamanan pasokan energi (energy security) sangat penting, memerlukan derajat keandalan (reliability) dan ketersediaan (availability) yang sangat tinggi. HTGR mempunyai keandalan yang tinggi dan ketersediaan yang memadai sehingga dapat menjamin pasokan kontinuitas energi untuk produksi hidrogen steam reforming[8].

Dalam makalah ini akan dibahas sistem pasokan energi panas pada proses steam reforming gas alam antara proses konvensional dan proses dengan energi nuklir. Sistem 
pasokan panas untuk proses produksi hidrogen dengan proses steam reforming gas alam dan dengan memanfaatkan panas nuklir berbeda. Studi ini bertujuan menganalisis pasokan panas untuk proses produksi hidrogen proses steam reforming dengan bahan bakar gas alam dan dengan memanfaatkan panas nuklir. Hasil studi diharapkan dapat memberi masukan bagi pengambil kebijakan dalam pengambilan keputusan, guna peningkatan efisiensi produksi hidrogen dengan memanfaatkan panas nuklir, dalam rangka menyongsong pembangunan PLTN di Indonesia

\section{METODOLOGI}

Metodologi yang digunakan dalam analisis pasokan panas adalah kajian literatur dengan membandingkan kelebihan dan kelemahan produksi hidrogen dengan proses steam reforming gas alam proses konvensional dan nuklir.

\section{PASOKAN PANAS PADA PROSES STEAM REFORMING}

\subsection{Proses Steam Reforming Gas Alam}

Ada 2 reaksi utama yang terjadi pada proses steam reforming gas alam. Pertama, reaksi reforming yang merupakan reaksi sangat endotermis yang terjadi pada temperatur tinggi. Reaksi kedua adalah shift reaction, merupakan reaksi eksotermis yang bertujuan untuk mengontrol kuantitas produk yang diinginkan. Total dari reaksi (1) dan (2) adalah reaksi (3), yang secara termodinamika merupakan reaksi endotermis ${ }^{[2,9,10]}$.

$$
\begin{aligned}
& \text { Reaksi reforming } \quad \mathrm{CH}_{4}+\mathrm{H}_{2} \mathrm{O} \rightleftarrows \mathrm{CO}+3 \mathrm{H}_{2}-206 \mathrm{~kJ} / \mathrm{mol} \\
& \text { Water-shift reaction } \mathrm{CO}+\mathrm{H}_{2} \mathrm{O} \rightleftarrows \mathrm{CO}_{2}+\mathrm{H}_{2}+41 \mathrm{~kJ} / \mathrm{mol} \\
& \text { Total reaksi } \quad \mathrm{CH}_{4}+2 \mathrm{H}_{2} \mathrm{O} \rightleftarrows \mathrm{CO}_{2}+4 \mathrm{H}_{2}-165 \mathrm{~kJ} / \mathrm{mol}
\end{aligned}
$$

Pada sistem konvensional, reaksi pembentukan hidrogen terjadi pada unit reforming pada kisaran temperatur $850-900^{\circ} \mathrm{C}$, dan tekanan 2-3 MPa dengan katalisator berbasis nikel. Sejumlah desain dilengkapi dengan reaktor khusus untuk water-shift reaction ${ }^{[11]}$, untuk memperkaya produk hidrogen. Beberapa teknologi menggunakan unit pre-reformer telah dikembangkan ${ }^{[12]}$. Unit ini berfungsi menjalankan sebagian proses reforming dan mengkonversi senyawa alkana $\mathrm{C}_{2}$ atau lebih menjadi metana. Setelah dari pre-reformer, diumpankan lagi ke unit reformer untuk menyempurnakan reaksi reforming yang belum terjadi pada pre-reformer. Dengan adanya pre-reformer, terbuka peluang penggunaan bahan baku bukan gas alam saja, tetapi dapat juga berbagai hidrokarbon turunan minyak bumi yang lain ${ }^{[13]}$. Pre-reformer juga akan menurunkan beban energi panas yang diperlukan pada proses reforming, serta mengurangi akumulasi gas alam sisa yang harus didaur ulang yang membutuhkan energi tersendiri dan menurunkan efisiensi thermal[14,15,16]. Diagram alir produksi hidrogen dengan proses steam reforming gas alam dapat dilihat pada Gambar 1.

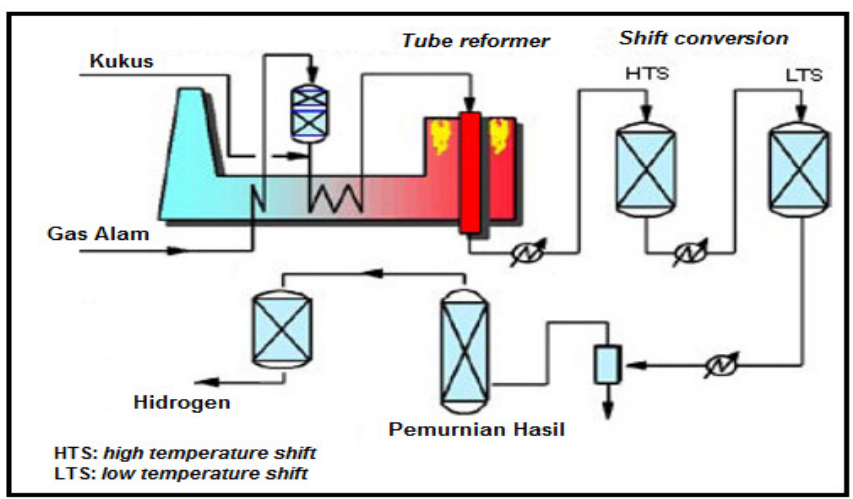

Gambar 1. Diagram Alir Proses Steam Reforming Gas Alam ${ }^{[2,17]}$. 


\subsection{Sistem Pasokan Panas Proses Konvensional}

Reaksi kimia yang terjadi pada reformer adalah reaksi endotermis pada temperatur tinggi. Ini berimplikasi dibutuhkannya panas dalam jumlah besar dan temperatur tinggi secara kontinu. Pada sistem konvensional, reaktor reformer merupakan reaktor tabung tegak berisi tumpukan katalisator yang disusun secara paralel dan ditempatkan di dalam tungku untuk menerima panas dengan sistem pembakaran langsung. Tabung reformer biasanya mempunyai ukuran diameter luar 100-150 mm dan panjang 10-13 $\mathrm{m}^{[18]}$. Tabung reformer berjumlah antara 200-300 disusun secara paralel tegak di dalam tungku.

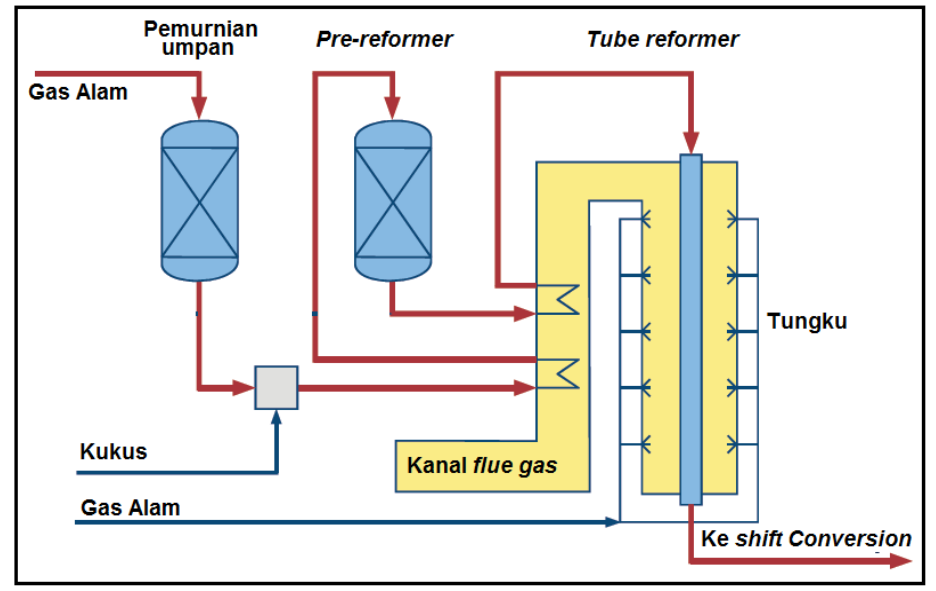

Gambar 2. Skema Pasokan Panas Pada Reformer ${ }^{[19,20] .}$

Energi panas dipasok dengan pembakaran langsung gas alam pada tungku, diarahkan langsung pada zona reaksi, yaitu tumpukan katalisator yang ada di dalam tabung reformer. Untuk meningkatkan pemanfaatan panas, panas dari kanal tungku dimanfaatkan sebagai pemanas awal bahan baku LNG dan kukus, sebelum diumpankan ke pre-reformer pada temperatur $300-350^{\circ} \mathrm{C}^{[21]}$. Luaran gas dari pre-reformer terdiri dari $\mathrm{CO}, \mathrm{CO}_{2}$ dan $\mathrm{CH}_{4}$ sisa, dipanaskan lagi memanfaatkan kanal tungku sebelum diumpankan ke reformer pada temperatur $450-600^{\circ} \mathrm{C}$. Reaksi reforming akan terjadi secara optimum pada zona katalisator pada temperatur $850-900^{\circ} \mathrm{C}$. Produk kaya hidrogen keluar dari reformer pada temperatur $850-900^{\circ} \mathrm{C}$ diproses lebih lanjut. Kisaran tekanan operasi optimum adalah 2,5-3 MPa, menghasilkan produk gas hidrogen $86-90 \%{ }^{[22]}$. Rasio $\mathrm{H}_{2} \mathrm{O} / \mathrm{CH}_{4}$ minimum sekitar 2 diperlukan untuk menghindari terjadinya deposisi karbon terhadap katalisator.

Sistem pasokan panas dengan tungku dan pembakaran langsung memberikan keuntungan pola perpindahan panas yang didominasi oleh perpindahan panas radiasi. Hal ini memberikan fluks panas optimum di zona katalisator, yaitu berkisar $50-80 \mathrm{~kW} / \mathrm{m}^{2}$, sehingga diperoleh efisiensi thermal yang tinggi $(85 \%)^{[23]}$.

\subsection{Sistem Pasokan Panas Proses dengan Nuklir}

Salah satu reaktor yang potensial untuk aplikasi energi panas temperatur tinggi adalah reaktor nuklir temperatur tinggi berpendingin gas (HTGR) ${ }^{[24]}$. Secara umum, HTGR dimanfaatkan untuk menghasilkan listrik. Pada perkembangannya, reaktor nuklir generasi IV dirancang bukan saja untuk menghasilkan listrik, tetapi juga mempunyai kemampuan pemanfaatan energi panas yang dihasilkan untuk proses industri. HTGR merupakan cikal bakal reaktor generasi IV yang potensial untuk aplikasi panas nuklir untuk proses industri. Reaktor ini beroperasi pada temperatur tinggi sampai $950^{\circ} \mathrm{C}$. Luaran pendingin reaktor yang dibawa media pendingin gas helium mempunyai temperatur sekitar $900^{\circ} \mathrm{C}$ yang dapat dimanfaatkan untuk aplikasi panas. 
Pada Gambar 3 ditunjukkan skema kopling VHTR (Very High Temperature Reactor) yang merupakan salah satu jenis HTGR, dengan proses steam reforming gas alam ${ }^{[25,26]}$. Pada Gambar 3 terlihat bahwa luaran pendingin reaktor yang dibawa helium primer dengan temperatur $900^{\circ} \mathrm{C}$ memindahkan panasnya ke Intermediate Heat Exchanger (IHX), yang merupakan alat pertukaran panas dengan media helium. Helium sekunder dengan temperatur $890^{\circ} \mathrm{C}$ dimanfaatkan untuk proses. Aliran gas helium masuk ke reformer dari bawah pada temperatur $890^{\circ} \mathrm{C}$, sementara gas alam dan kukus diumpankan dari atas pada temperatur $450^{\circ} \mathrm{C}$. Luaran gas helium pada $800^{\circ} \mathrm{C}$ dan gas hasil pada $600^{\circ} \mathrm{C}$ dimanfaatkan untuk pemanas kukus pada HRSG (heat recovery steam generator) sehingga diperoleh kukus pada temperatur $450^{\circ} \mathrm{C}$ untuk diumpankan ke reformer. Selanjutnya helium sekunder dimasukkan lagi ke IHX, sedang gas hasil diproses lebih lanjut.

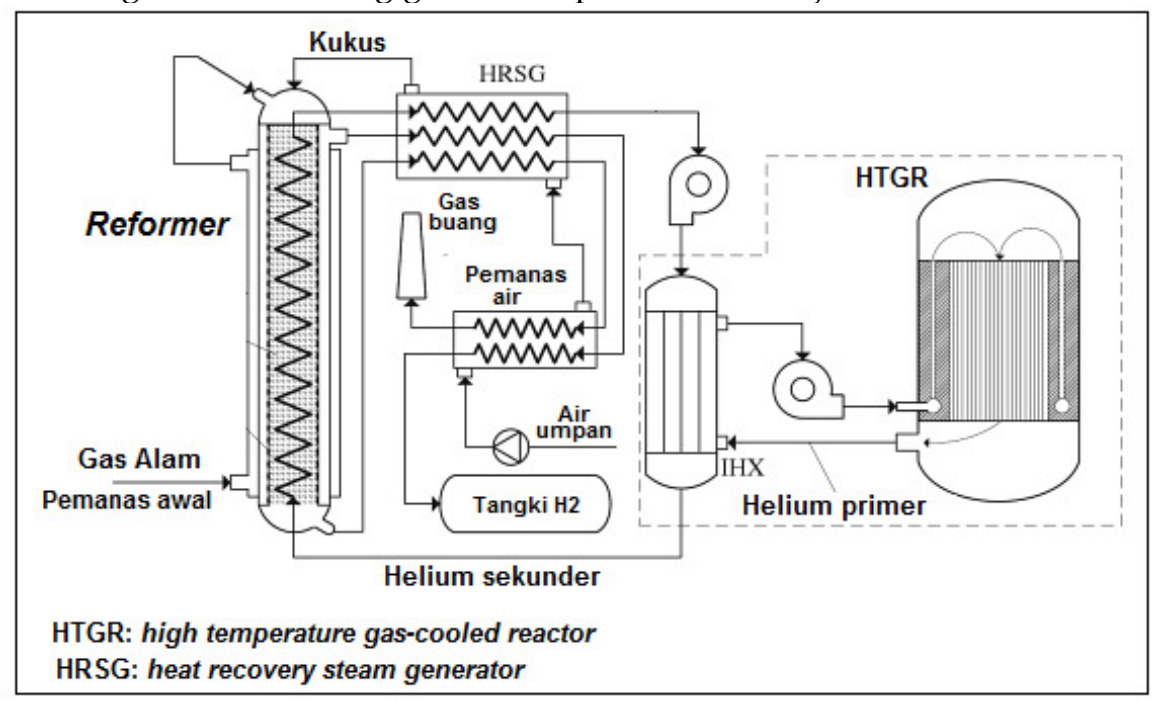

Gambar 3. Kopel Energi Panas Nuklir dengan Steam Reforming Gas Alam ${ }^{[26]}$.

Berbeda dengan sistem pasokan panas proses konvensional yang dilakukan dengan pembakaran langsung gas alam, pada proses steam reforming gas alam dengan nuklir, pasokan energi panas diberikan dengan media pemanas helium sekunder. Untuk itu, reformer yang digunakan adalah sistem shell and tube. Pada Gambar 4 ditunjukkan reformer yang dirancang oleh Jepang yang mengadopsi sistem alat penukar panas shell and tube yang disebut dengan tipe bayonet. Terlihat pada Gambar 4, tube reformer dirancang bentuk double tube $\mathrm{U}$ (disebut bayonet) yang berisi tumpukan katalisator, ada di dalam shell. Umpan gas alam dan kukus masuk ke dalam tube dari atas turun melalui tumpukan katalisator, sampai dasar tube masuk ke dalam pipa yang ada dalam $U$-tube dan kembali lagi mengalir ke atas. Helium dari pendingin sekunder masuk ke dalam refomer mengalir dari dasar ke atas sepanjang shell dan memindahkan panasnya di sepanjang zona katalisator. Perpindahan panas yang terjadi dari pemanas helium ke zona katalisator didominasi oleh perpindahan panas konveksi paksa. Hal ini mengakibatkan fluks panas yang tercapai pada zona katalisator hanya $10-20 \mathrm{~kW} / \mathrm{m}^{2}$, atau seperempat dibanding proses konvensional. Rendahnya fluks panas yang dapat mencapai zona katalisator mengakibatkan rendahnya efisiensi thermal proses. Studi di Jepang menunjukkan bahwa efisiensi thermal yang diperoleh hanya sekitar 50\%, jauh lebih rendah dibanding proses konvensional yang mencapai $85 \%{ }^{[27]}$. 


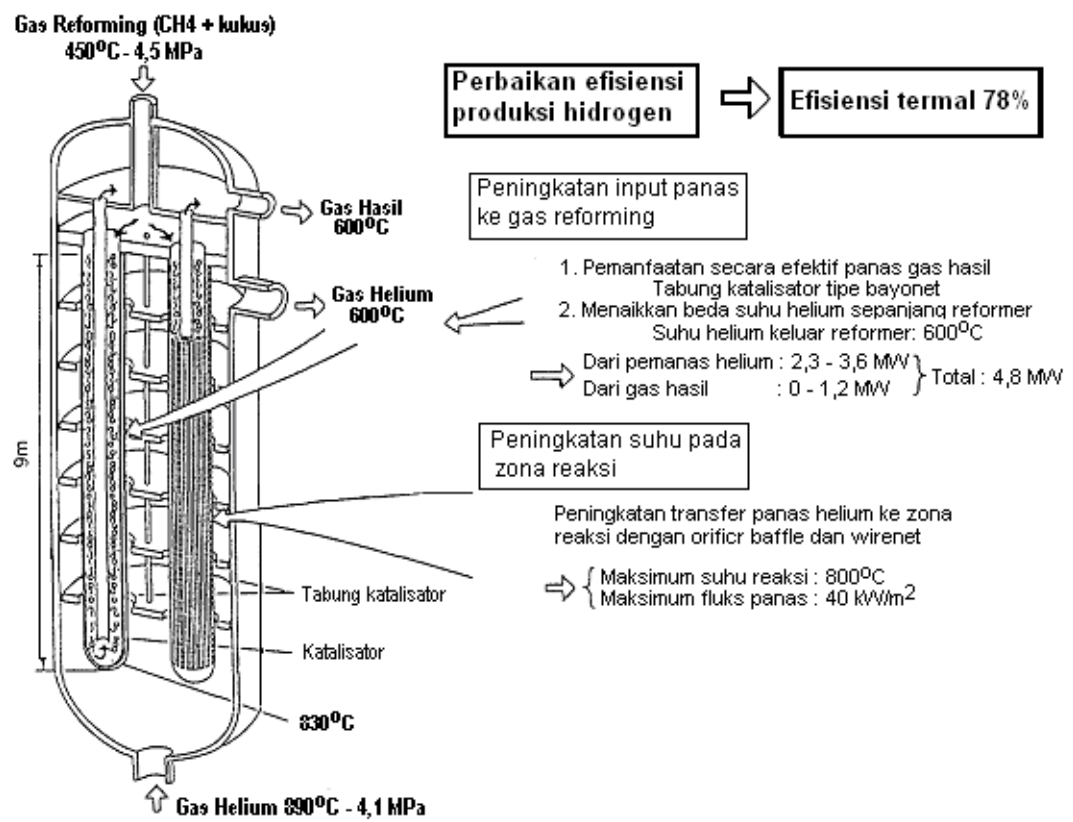

\section{Gambar 4. Reformer tipe Bayonet dan prinsip peningkatan efisiensi ${ }^{[27,28]}$.}

Efisiensi thermal yang rendah pada sistem dengan energi nuklir mendorong perlunya modifikasi proses dan reformer terkait dengan sistem pasokan panas. Gas helium yang keluar dari reformer dimanfaatkan untuk memanaskan gas reforming yaitu umpan $\mathrm{CH}_{4}$ dan kukus sampai temperatur $450^{\circ} \mathrm{C}$. Dengan cara ini diperoleh 2 keuntungan yaitu ketika gas umpan mencapai zona tabung katalisator, temperaturnya dapat naik mencapai $830^{\circ} \mathrm{C}$. Gas helium yang keluar dari reformer, karena panasnya dimanfaatkan, maka temperaturnya turun menjadi $600^{\circ} \mathrm{C}$. Peningkatan beda temperatur antara helium masuk dan keluar akan meningkatkan input panas ke tabung katalisator. Dengan cara ini, total panas yang dapat mencapai tabung katalisator tidak saja berasal dari gas helium yang masuk ke reformer tapi juga berasal dari gas helium yang keluar dari reformer ${ }^{[23,27,29]}$.

Tabel 1. Perbandingan Kinerja Steam Reformer ${ }^{[7,27]}$

\begin{tabular}{cccc}
\hline Reformer & Konvensional & $\begin{array}{c}\text { HTGR } \\
\text { (tanpa modifikasi) }\end{array}$ & $\begin{array}{c}\text { HTGR } \\
\text { (modifikasi reformer) }\end{array}$ \\
\hline Tekanan Operasi & $1-3 \mathrm{MPa}$ & $>4.1 \mathrm{MPa}$ & $\begin{array}{c}\text { Keseimbangan Tekanan } \\
(\cong \mathrm{PHe})\end{array}$ \\
Temperatur Operasi, ${ }^{\circ} \mathrm{C}$ & $850 \mathrm{MPa}$ \\
Fluks panas, $\mathrm{kW} / \mathrm{m}^{2}$ & $50-800$ & $\leq 800$ & 830 \\
Efisiensi thermal, $\%$ & $80 \sim 85$ & $10-20$ & 40 \\
\hline
\end{tabular}

Peningkatan temperatur reaksi pada tabung katalisator juga dilakukan dengan memperlama waktu tinggal (residence time) gas helium di dalam reformer dengan memasang orifice baffle, dan memperbesar luas permukaan perpindahan panas dengan wirenet. Ini sesuai dengan prinsip perpindahan panas, semakin lama waktu tinggal dan semakin besar luas permukaan perpindahan panas, maka akan semakin optimum proses perpindahan panas. Dengan cara ini tidak saja temperatur operasi pada tabung katalisator dapat mencapai $830^{\circ} \mathrm{C}$, perpindahan panas juga dapat meningkat secara optimum sehingga fluks panas pada tabung katalisator dapat mencapai $40 \mathrm{~kW} / \mathrm{m}^{2}$. Dengan modifikasi sistem 
pasokan panas dan pada reformer diperoleh efisiensi thermal yang lebih baik (78\%) walaupun masih lebih rendah sedikit daripada proses dengan sumber panas konvensional[7]. Perbandingan kinerja reformer dapat dilihat pada Tabel 1.

\section{PEMBAHASAN}

Perbedaan utama pasokan panas pada proses steam reforming konvensional dan proses nuklir terletak pada sumber energi yang digunakan untuk pemanas awal umpan gas alam dan reformer. Pada proses konvensional, energi yang digunakan berasal dari pembakaran langsung gas alam, sedangkan pada proses nuklir berasal dari media pemanas helium IHX. Sebagai catatan, pada proses pemanfaatan panas nuklir, total panas ke reformer tidak hanya berasal dari gas helium yang masuk dari reformer tetapi juga dari gas helium yang keluar reformer. Perbedaan lain dari ke dua proses ini juga terletak pada jenis perpindahan panas. Pada proses konvensional didominasi perpindahan panas radiasi, sedangkan pada proses nuklir didominasi oleh perpindahan panas konveksi paksa.

Dari uraian sebelumnya, diketahui bahwa kelemahan proses dengan pemanfaatan panas nuklir antara lain disebabkan keterbatasan temperatur sumber panas dan sistem pasokan panas, serta pola perpindahan panas. Secara teoritis, luaran pendingin reaktor nuklir yang dibawa helium primer pada temperatur sekitar $950^{\circ} \mathrm{C}$ memenuhi sebagai sumber panas proses steam reforming yang pada proses konvensional beroperasi pada temperatur $850-900^{\circ} \mathrm{C}$.

Beberapa tuntutan faktor keselamatan terkait pemanfaatan energi panas nuklir mengakibatkan sistem pasokan panas dengan energi nuklir memberikan efisiensi lebih rendah dibanding proses konvensional.

IHX yang merupakan alat penukar panas helium-helium, diperlukan untuk menghindari sekecil mungkin terjadinya kontaminasi radioaktif di zona proses kimia ${ }^{[30]}$. IHX merupakan interface antara zona nuklir dengan zona proses kimia, dan berfungsi sebagai barrier yang memisahkan zona nuklir dengan zona kimia. Studi di Jepang menunjukkan jarak aman antara kedua zona adalah sekitar 50-130 meter ${ }^{[9]}$.

Proses konvensional beroperasi pada tekanan optimum sebesar $3 \mathrm{MPa}$. Pada penggunaan energi panas nuklir, jika tekanan operasi didesain sama, ini menyalahi prinsip aplikasi energi nuklir bahwa tekanan di wilayah non radioaktif dirancang harus lebih besar daripada tekanan di wilayah radioaktif. Maka desain tekanan harus lebih besar daripada tekanan operasi reaktor nuklir $(4,1 \mathrm{MPa})$. Suatu studi menunjukkan bahwa tekanan operasi berpengaruh secara signifikan terhadap efisiensi thermal. Pada temperatur operasi sebesar $800^{\circ} \mathrm{C}$, jika tekanan operasi sebesar 4,5 MPa akan dicapai efisiensi thermal sebesar $64 \%$. Jika tekanan diturunkan menjadi $2 \mathrm{MPa}$ dan $1 \mathrm{MPa}$, efisiensi thermal masing-masing meningkat menjadi $81 \%$ dan $92 \%{ }^{[31]}$.

Penggunaan IHX dan penerapan tekanan operasi yang lebih tinggi merupakan kelemahan sistem dengan energi nuklir. Pemanfaatan IHX akan menurunkan temperatur sumber energi panas dari $900^{\circ} \mathrm{C}$ menjadi hanya $890^{\circ} \mathrm{C}^{132]}$. Dengan masukan temperatur sebesar $890^{\circ} \mathrm{C}$, tekanan lebih besar dari 4,1 $\mathrm{MPa}$, dan pola perpindahan panas didominasi perpindahan panas konveksi paksa, fluks panas yang dapat mencapai tabung katalisator hanya sekitar $10-20 \mathrm{~kW} / \mathrm{m}^{2[23,32]}$. Sebagai perbandingan, pada proses konvensional komersial, energi panas pembakaran bahan bakar fosil masuk ke reformer pada temperatur sekitar $950^{\circ} \mathrm{C}$, dan karena proses perpindahan panas yang terjadi antara sistem pemanas dengan daerah katalisator adalah radiasi thermal maka fluks panas yang dihasilkan dapat mencapai $50-80 \mathrm{~kW} / \mathrm{m}^{2}$, jauh lebih besar dibanding proses dengan panas nuklir. 
Modifikasi reformer yang prinsipnya untuk meningkatkan efektivitas perpindahan panas, seperti terlihat pada Gambar 4, dapat meningkatkan fluks panas pada tabung katalisator menjadi sebesar $40 \mathrm{~kW} / \mathrm{m}^{2}$, seperti terlihat pada Tabel 1 .

Pemanfaatan energi nuklir sebagai sumber energi panas, meskipun dari sisi efisiensi thermal sedikit lebih rendah, tetapi dari aspek penghematan bahan bakar fosil dan emisi lingkungan jauh lebih baik. Suatu studi menyebutkan bahwa dengan aplikasi panas nuklir, produksi hidrogen dengan kapasitas 200 ton/hari membutuhkan gas alam sebesar 21,3 juta MMBTU per tahun, yang masing-masing digunakan untuk bahan baku 8,9 juta MMBTU, energi panas 6,2 juta MMBTU dan sebagai bahan bakar untuk listrik dan kukus sebesar 6,2 juta MMBTU[5]. Sehingga penggantian energi fosil dengan energi nuklir dapat menghemat kebutuhan gas alam untuk energi panas (panas, kukus, listrik) sebesar 12,4 juta MMBTU per tahun $(57 \%)$ yang setara dengan potensi pengurangan laju emisi $\mathrm{CO}_{2}$ sebesar $718.196,42$ ton/tahun ${ }^{[5]}$.

\section{KESIMPULAN}

Pada steam reforming gas alam, sumber panas bahan bakar fosil (gas alam) mampu memberikan kondisi operasi optimum temperatur $850-900^{\circ} \mathrm{C}$ dan tekanan $2-3 \mathrm{MPa}$, serta perpindahan panas didominasi oleh perpindahan panas radiasi, sehingga fluks panas yang dapat dicapai pada tabung katalisator relatif tinggi yaitu $50-80 \mathrm{~kW} / \mathrm{m}^{2}$ dan menghasilkan efisiensi thermal yang tinggi sekitar $85 \%$. Sedang pada sistem dengan memanfaatkan panas dari energi nuklir, karena tuntutan keselamatan, proses beroperasi pada kondisi yang kurang optimum pada temperatur $800-850^{\circ} \mathrm{C}$ dan tekanan $4,5 \mathrm{MPa}$, serta dengan perpindahan panas didominasi oleh perpindahan panas konveksi, sehingga fluks panas yang dapat dicapai pada tabung katalisator jauh lebih rendah $\left(10-20 \mathrm{~kW} / \mathrm{m}^{2}\right)$ dan menghasilkan efisiensi thermal yang rendah yaitu sekitar $50 \%$. Modifikasi reformer dan utilisasi panas mampu meningkatkan fluks panas sampai $40 \mathrm{~kW} / \mathrm{m}^{2}$ sehingga efisiensi thermal dapat mencapai 78\%. Meskipun demikian, aplikasi energi nuklir mampu menghemat pembakaran bahan bakar fosil yang berimplikasi pada penurunan laju emisi $\mathrm{CO}_{2}$ ke lingkungan.

\section{DAFTAR PUSTAKA}

[1]. FORSBERG, C., "Meeting U.S. Liquid Transport Fuel Needs with A Nuclear Hydrogen Biomass System", International Journal Hydrogen Energy, 34 (9), 2009.

[2]. THOHARUDIN, et.al., "Methane Steam Reforming to Produce High Ratio of Hydrogen to Carbon Monoxide by Using CFD", International Conference and Exhibition on Sustainable Energy and Advanced Materials, Indonesia, 2011.

[3]. YOUVIAL, M., "Polymer Electrolyte Membrane Fuel Cell dan Pembahasan Umpan Hidrogen", Jurnal Ilmiah Teknologi Energi, Vol.1, No.3, 2006.

[4]. VERFONDERN, K., LENSA,W., "European Research and Development on HTGR Process Heat Applications", Proc. of Int. Conference GENES4/ANP2003, Kyoto, 2003.

[5]. SALIMY, D. H., "Aplikasi Energi Panas Nuklir Temperatur Tinggi pada Pabrik Pupuk Urea", Jurnal Pengembangan Energi Nuklir Vol.14, No. 1, 2012.

[6]. RUTH, M. F., et.al., "Nuclear-Renewable Hybrid Energy Systems : Opportunities, Inter-Connections and Needs", Journal of Energy Conversion and Management 78, 2014.

[7]. HORI, M., SHIOZAWA, S., "Research and Development for Nuclear Production of Hydrogen in Japan", Proceeding of OECD/NEA 3rd Information Exchange Meeting on the Nuclear Production of Hydrogen, Japan, 2005. 
[8]. YIN, H., et.al., "Modeling of The Helium-Heated Steam Reformer for HTR-10", Journal of Nuclear Science and Technology, Vol. 44, No. 7, 2007.

[9]. VERVONDERN, K., "Nuclear Energy for Hydrogen Production", Forschungszentrum Jülich GmbH, Volume 58, Jerman, 2007.

[10]. PADBAN, N., BECHER, V., "Clean Hydrogen-Rich Synthesis Gas: Literature and State-of-The-Art Review", Report No. CHRISGAS October, 2005.

[11]. Hydrogen Production by Steam Reforming : Management of The Gas is Critical for Petroleum Refiners, Ray Elshout Energy, Chemical Engineering Processing, 2010, diakses Pebruari 2015.

[12]. UDENGAARD, N. R., "Hydrogen Production by Steam Reforming of Hydrocarbons", Journal of Am. Chem. Soc., Div. Fuel Chem. 49(2), 2004.

[13]. CHEN,W. H., et.al., "Thermodynamic Analysis of Hydrogen Production from Methane via Autothermal Reforming and Partial Oxidation Followed by Water Gas Shift Reaction", International Journal Hydrogen Energy 35(21), 2010.

[14]. PENG, X. D., Analysis of The Thermal Efficiency Limit of "The Steam Methane Reforming Process", Journal of Ind. Eng. Chem. Res., 51, 2012.

[15]. YANG, J. I., "Combined Pre-Reformer/Reformer System Utilizing Monolith Catalysts for Hydrogen Production", International Journal of Hydrogen Energy, 36, 2011.

[16]. HARYATI, S., BUSTAN, M. D., ASNANI, J., "Studi Efek Kinetika Katalis Platina, Paladium, Kobalt dan Nikel terhadap Produksi Syngas di Steam Reformer PT Pusri II Palembang", Proceeding of Second Added Value of Energy Resources, Palembang, 2009.

[17]. Steam Reforming Hydrogen for Both Waste Management and Hydrogen Production http://www.making-hydrogen.com/steam-reforming-hydrogen.html, diakses Pebruari 2015.

[18]. MOLBURG, J. C., DOCTOR, R. D., “Hydrogen from Steam-Methane Reforming with CO2 Capture", Proceeding of 20th Annual International Pittsburgh Coal Conference, 2003.

[19]. LIU, J. A., "Kinetics, Catalysis and Mechanism of Methane Steam Reforming", Thesis of Chemical Engineering Dept., Worcester Polytechnic Institute, 2006.

[20]. OLSSON, H., et.al., Adding Hydrogen Production Capacity by Heat Exchange Reforming", Proceeding of The XIV Refinery Technology Meet (RTM) on Energy \& Environment Challenges for the Hydrocarbon Sector, 2007.

[21]. CARCADEA, E., VARLAM, M., STEFANESCU, I., "Heat Transfer Modelling of Steam Methane Reforming", Proceeding of 2012 COMSOL Conference, Milan, 2012.

[22]. www. BRHS Chap2_Engineering_version_0_9_0. pdf, "Hydrogen Technologies", diakses Pebruari 2015.

[23]. HORI, M., "Synergistic Energy Conversion Processes Using Nuclear Energy and Fossil Fuels", Proceeding of International Symposium on the Peaceful Applications of Nuclear Technology in the GCC Countries, Jeddah, 2008.

[24]. ALIMAH, S., dkk., "Aspek Termodinamika Produksi Hidrogen Dengan Proses Steam Reforming Gas Alam", Majalah Ilmiah Pengkajian Industri, Vol. 4 No. 1, April, 2010.

[25]. CASPERSSON, S. A., "Process Heat and Hydrogen Generation with the PBM Modular Reactor", Proceeding of NSF Symposium on Advanced Thermal Processing, Boston, 2008.

[26]. NATERER, G. F., DINCER, I., ZAMFIRESCU, C., "Hydrogen Production from Nuclear Energy", Springer Science \& Business Media Publication, London 2013.

[27]. FUJIMOTO, N., et.al., "Present Status of HTTR Project, Achievement of 950oC of Reactor Outlet Cooolant Temperature, GTHTR300C for Hydrogen Cogeneration", 
Proceeding of OECD/NEA 3rd Information Exchange Meeting on the Nuc. Production of H2, 2005.

[28]. SALIMY, D. H., “Aspek Keselamatan Pada Aplikasi Reaktor Nuklir Temperatur Tinggi untuk Proses Steam Reforming Gas Alam", Jurnal Pengembangan Energi Nuklir Vol. 10 No. 1, 2008.

[29]. SAFA, H., "Heat Recovery from Nuclear Power Plants", Int. J. Electr. Power Energy Syst. 42(1), 2012.

[30]. SHIINA, Y., NISHIHARA, T., "Cost Estimation of Hydrogen and DME Produced by Nuclear Heat Utilization System II", JAERI-Tech. 2004-057, 2004.

[31]. CASTAGNOLA, L., LOMONACO, G., MAROTTA, R., "Nuclear Systems for Hydrogen Production: State of Art and Perspectives in Transport Sector", Global Journal of Energy Technology Research, 1, 2014.

[32]. SATO, H., "Control Strategies for Transients of Hydrogen Production Plant in VHTR Cogeneration Systems", Progress in Nuclear Energy 53(7), 2011. 